Transitions

$\mathrm{X}$ Martin Hollenhorst will take up his new post as chief financial officer for Heidelbergbased LION Bioscience in April. Hollenhorst comes to LION after spending some time in Washington DC as a freelance management consultant. He will replace Klaus Sprockamp, who died in the 11 September attack on the World Trade Center.

X Damian Marron was this month appointed senior director, business development, for $\mathrm{Nic} \mathrm{Ox}$ a drug firm based in Sophia Antipolis, France. Marron is a former head of European business development for 3M Pharmaceuticals, which he joined in 1997.

X Last month Ardana Bioscience, an Edinburgh-based biotech company focused on women's reproductive health, appointed Finn Larsen, previously medical director at Columbia Laboratories, Paris, France, as its clinical director.

X Last month Lester Crawford was named deputy commissioner of the US Food and Drug Administration. Crawford most recently served as head of the Center for Food and Nutrition Policy at Virginia Tech in Blacksburg.

X Julia King, director of marine engineering and technology at UK-based company Rolls-Royce, will this September succeed Alun Jones as chief executive of the Institute of Physics.

X Michael Wokasch, president of Vertex Pharmaceuticals subsidiary PanVera, had his role expanded this month. In addition to his post as PanVera, he will now serve as president of another Vertex subsidiary, Aurora Biosciences, where he replaces Harry Stylli.

\section{HIGH-ENERGY PHYSICS}

After 14 years at Cornell University in Ithaca, high-energy physicist Persis Drell is moving to the Stanford Linear Accelerator Center (SLAC) in Menlo Park, California. She steps into her new role as associate director of SLAC's research division next month. She replaces Steve Williams, who had been acting associate director since September 2000.

Drell says she will miss Ithaca, but she feels that SLAC's larger size and broader programme - which she believes could help scientists to push the boundaries of the standard model — will be adequate compensation.

One of the attractions of her new post is the combination of additional management responsibilities and a continued freedom to be involved in experiments. "This lets me stretch my administrative wings but keeps me close to the science," Drell says.

Drell's decision to move was made easier by the fact that Stanford has also hired her husband, Jim Welch, who is an accelerator physicist. This solved the "two-body problem" that can limit the options for some academics, she says.

\section{BIOCHEMISTRY}

Roger Dean, former director of the Heart Research Institute in Sydney, last month assumed the position of vice-chancellor at the University of Canberra. Dean describes himself as a "biochemist and musician" as well as his scientific interests, he is a keen composer involved in musical improvisation. He says that his new position will allow him to use "both sides of my brain", as he will be involved in both science and the humanities.

Dean plans to expand the teaching and research efforts at the university, and extend both its commercial and community outreach.

\section{BIOTECHNOLOGY}

Alan Colman, one of the scientists who helped to clone Dolly the sheep in 1996, is to leave his post as research director of Scottish firm PPL Therapeutics to become chief scientific officer at ES Cell International in Singapore. Colman is moving primarily because he believes that Singapore will offer a better investment climate for stem-cell research compared with Britain.

Australia's Monash University, a world leader in stem-cell technology, was one of the founding institutions behind ES Cell International. The company's location allows it to benefit from light regulation

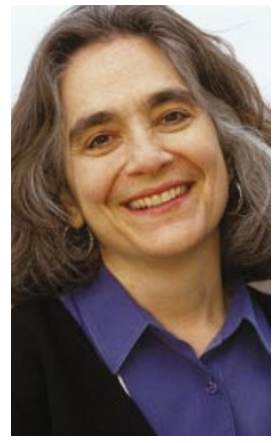

Persis Drell

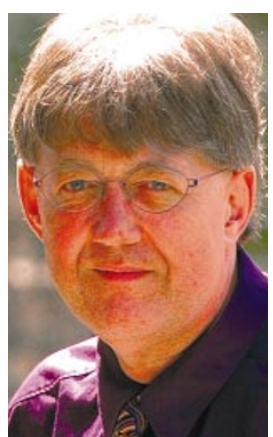

Roger Dean

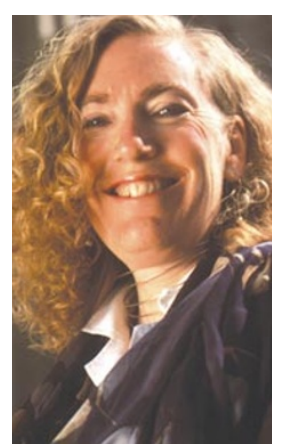

Elaine Fuchs

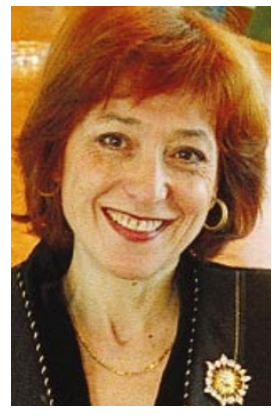

Noëlle Lenoi

\section{CONTACTING US} AT MOVERS

Please send any information on appointments or job moves to: naturejobseditor @naturedc.com. and a share of a $£ 400$-million (US\$570million) biomedicine investment fund, which was set up by the Singapore government in 2000 .

The announcement of Colman's move comes less than a year after Roger Pedersen decided to leave a faculty position at the University of California, San Francisco, for a similar post at the University of Cambridge because of Britain's more permissive policies towards stem-cell research (see Nature 412, 262; 2001).

\section{CELL BIOLOGY}

The "20-year-itch" has helped to convince Elaine Fuchs, past president of the American Society for Cell Biology, to leave the University of Chicago and head for Rockefeller University to lead the Mammalian Cell Biology and Development Laboratory. Fuchs and her friend Susan Lindquist, who last year left Chicago to direct the Whitehead Institute in Cambridge, Massachusetts (see Movers, Naturejobs 30 August 2001), had both done some soul-searching and decided to shake up their careers a little.

Although she enjoyed her 20 years at Chicago, the past few years left Fuchs feeling that things were getting a little too familiar. Rockefeller will give her "a new environment with new colleagues taking different approaches to different problems", she says. She is especially interested in interacting with neuroscientists and structural biologists to develop her research in the biology of the skin.

\section{LAW}

Noëlle Lenoir, former Justice of the French Constitutional Supreme Court, is enjoying her new position as a biotech lawyer with the firm Herbert Smith in Paris, which she took up this winter. "In France it's not so easy to go from the public sector to the private sector," she says. But she notes that working in the public sector "opened a lot of doors" for her.

Apart from her Supreme Court position, Lenoir served on bioethics panels for both the United Nations and the European Union. Doors are now starting to open for her in the French biotech sector, she says, which is beginning to expand as a result of increased investment.

Lenoir serves the law firm as a specialist in biotech patents and pharmaceutical law. At the same time she is a visiting professor at University College London and Yale University in Connecticut. "My life is quite an exciting challenge for a former Justice," she says. 